\title{
How Online Learning Evaluation (Kahoot) Affecting Students' Achievement and Motivation (Case Study on it Students)
}

\author{
Ratu Dea Mada1,a, Anharudin',b \\ ${ }^{1}$ Accounting Information System, Vocational Education Program, Serang Raya University, 42116, Banten, Indonesia \\ 2Department of Computer Engineering System, Faculty of Informatics Technology, Serang Raya University, 421161, Banten, Indonesia \\ a ratudeamada@gmail.com; b anhar.dean@gmail.com \\ ${ }^{*}$ Corresponding Author \\ Whatsapp number: [+62-87808533114]
}

How to Cite : Mada, R., D., Anharudin, A. (2019). How Online Learning Evaluation (Kahoot) Affecting Students' Achievement and Motivation (Case Study on it Students). International Journal for Educational and Vocational Studies, 1 (5), 422-427

\section{ARTICLE HISTORY}

Received: 13 June 2019

Revised: 20 July 2019

Accepted: 2 September 2019

\section{KEYWORDS}

Kahoot;

Motivation;

Students' achievement;

\section{ABSTRACT}

It is undeniable that the development of technology in the present impacts on various aspects, especially in the field of learning technology. In learning, lecturers are required to implement innovations in the field of technology. One of the implementations of education technology is the implementation of evaluation by using Kahoot. Kahoot is a game-based learning platform. By implementing this learning evaluation, we expect students' achievement and motivation in learning to improve. The research method of this research is simple qualitative descriptive using a questionnaire that were distributed to the first semester Informatics Engineering students as the object of this research. From the questionnaire the results showed that $82.2 \%$ of students stated that Kahoot was able to increase their learning motivation. Other results is the increasing of students' scores in this evaluations and the obstacle found in implementing this evaluation is the unstable connections or internet networks.

\section{INTRODUCTION}

Todays, Information and Communication Technologies are important in everyday live and become one of important things for people. People use technology in every part of their life. It influencing every aspects of life. One of this influence occur in education. This affect the ability of lecturer to master technology they use in learning activity. Many lectures are required technology in their teaching and learning activity. By using technology makes the learning activity more interesting. Conventional teaching by writing on the board or lecturing is considered outdated, so most lecturers today have used Information and Communication Technologies in their teaching, such as by using powerpoint, internet, online media, etc.

Likewise in the course of learning the Internet where it is still done conventionally as the results, it feels less attractive. Learners can become bored if they only listen to the lecturer's explanation. Even though language learning requires the use of ICT such as audio, video, etc. Likewise this applies in the evaluation of learning faced by students.

One form of assessment is using a test. Conventional tests such as written tests (paper-based tests) are still used in modern times, but the development of online-based tests has been very rapid. Lecturers and students also have to keep up with the times. By utilizing online tests, lecturers are easier and faster in evaluating. Paper-based tests are considered impractical and wasteful.

Recent studies shown that by using Information and Communication Tecnologies, the learning situation is more relaxed than the konvensional class (Kusumastuti, 2018:8). Other reasearch found that by using online learning evaluation (Kahoot), there was 94\% of students prefer using Kahoot that convetional tests. As many as $75 \%$ students fell happy when running Kahoot game and $87 \%$ increase the studets; motivation (Susanto, 2018)

In this case, we use Kahoot! as an evaluation media for online learning. By using Kahoot! It is expected that students can increase their motivation and learning outcomes.

This research aims to find out the benefits of the kahoot game in learning, To find out whether the kahoot game can increase students' motivation, to find out whether the kahoot game can increase the value of students and to find out the obstacles in implementing the kahoot game. 
Due some resesarch which have been shown that there are connection between the using of online learning game and students' motivation, the writers are eager to run research about this.

Learning motivation is the all activator power in the learner that stimulate into learning activities, which guarantees the continuity of learning activities and gives direction to learning activities, so that the objectives desired by the learning subject can be achieved (Sardiman, 1986: 75).

The benefits of learning motivation are giving encouragement to the students to learn and overcome learning difficulties, directing the learning activities of students to a specific goal related to the future and ideals and helping students to find an appropriate learning method in achieving the desired learning goals. (Hakim, 2008: 27)

In general, motivation can be grouped into two types (Prayitno, 1989: 10), namely: (1) intrinsic motivation, which is the impulse arises from the individual itself, and (2) extrinsic motivation, which is the impulse that arises because there is an external stimulus.

There are many ways to develop learning motivation (Nasution, 1982: 81), such as, providing value, giving a gift, announcing learning achievement, giving praise, growing interest in learning, and creating a pleasant learning atmosphere.

In this study the lecturer tried to arise the motivation of students by creating a pleasant learning atmosphere. Kahoot as a challenging and fun learning media is expected to generate motivation to learn.

Kahoot is a game based learning platform. Kahoot can be played via PC or smartphone. Kahoot can be accessed through www.kahoot.com and www.kahoot.it.

Lecturers can make multiple choice quizzes / questions that can be answered together at the same time. What distinguishes it from similar platforms is that participants must answer questions that come out quickly and correctly. Because there is competition from participants to answer faster than other participants, Kahoot is considered more exciting, challenging and fun.

Although Kahoot allows it to be done in a different place, Kahoot is best played in groups, for example, classrooms. How to play is not so difficult. What needs to be prepared is a large screen or screen to display questions. Lecturers as the host and share game PINs. Learners use an internet or PC connected to the internet, enter their game PIN through the website www.kahoot.it. Participants see questions on the screen, and choose answers in their own devices.

The advantages of using Kahoot that Kahoot be used for free, but when using Kahoot! Plus or Kahoot! Pro is charged a monthly fee, it Does not require an account to play quizzes, the quiz that we make can be shared with others. We can also use and edit quizzes made by other people,It support images and videos in the quiz created, and the participants' answers can also be documented. So that the lecturer does not need to make the evaluation report.

\section{METHODS}

This research method includes respondents from this study, population and samples, data collection techniques, and data analysis.

This study uses a descriptive method that aims to describe all responses given by students through a given questionnaire. The measurement scale used is a Likert scale with 3 indicators, namely 1 (Agree), 2 (Doubtful), 3 (Disagree).

The total population in this study were 45 students whom learn Internet Course in the 1st Semester of Informatics Engineering at Serang Raya University. The study was conducted in practical classes in two meetings in the first semester of the Academic Year 2018 -1919.

Data were obtained from the results of filling out a questionnaire containing 10 statements by 45 Semester 2 students of Information Engineering at Serang Raya University. The statements are grouped into 2 parts, the first part asks their opinion about Kahoot's media, the second part asks about the constraints Kahoot presented in essay queastion.

\section{RESULTS AND DISCUSSION}

A set of questionnaires containing 10 statements about Kahoot games that were distributed to 45 informatics engineering students, Serang Raya University semester 1 Academic Year 2018-2019, February to May 2018 period.

The questionnaire statement is divided into two groups, namely group 1 contains a statement about the Kahoot media (Table 1), group 2 contains a statement about the constraints of this media that are delivered in writing.

Tabel 1. Kahoot Online Evaluation

\begin{tabular}{cl}
\hline No & \multicolumn{1}{c}{ Questions } \\
\hline 1 & I prefer working in a team \\
\hline 2 & Kahoot game is more chalenging than paper based test \\
\hline 3 & Kahoot results are more objctive than paper based test \\
\hline 4 & I like when I am at the five top rank \\
\hline 5 & I like the resut that automatically shown \\
\hline 6 & This learning game is able to develop my learning motivation \\
\hline 7 & The learning environtment become more fun and interesting \\
\hline 9 & This learning game is able to develop the students' activity in the class. \\
\hline 10 & The question given is suitable with the subject of the course \\
\hline
\end{tabular}


From the question, the results are:

1. I prefer working in a team.

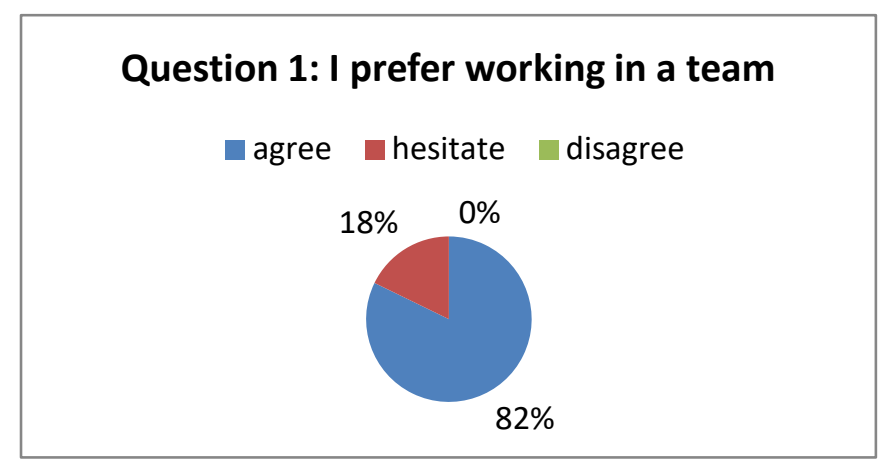

From the diagram above we can see that $82 \%$ from the respondent are prefer working in a team. And no student is anwering disagree for this statement.

2. Kahoot game is more chalenging than paper based test.

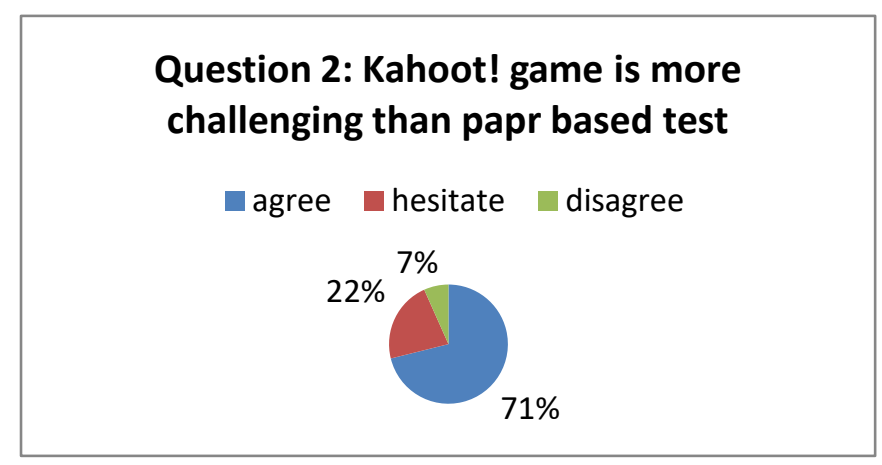

From the chart above, there are $71 \%$ of respondent agree that they are more challenged doing this game learning.

3. Kahoot results are more objctive than paper based test.

\section{Question 3: Kahoot results are more objectve than paper based test}

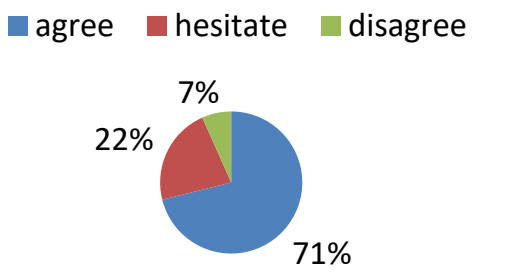

From the chart above as many as $71 \%$ of respondents agree that the resuts of Kahoot online game learning is more objective than paper based test.

4. I like when I am at the five top rank

\section{Question 4: I like when I am at the top five}

agree $\square$ hesitate disagree

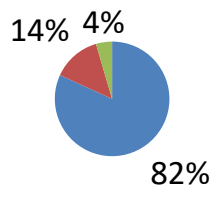

The chart above shown that as many as $82 \%$ respondent are like the competition side of this kahoot online learning game when they are at the op five rank.

5. I like the result that automatically shown

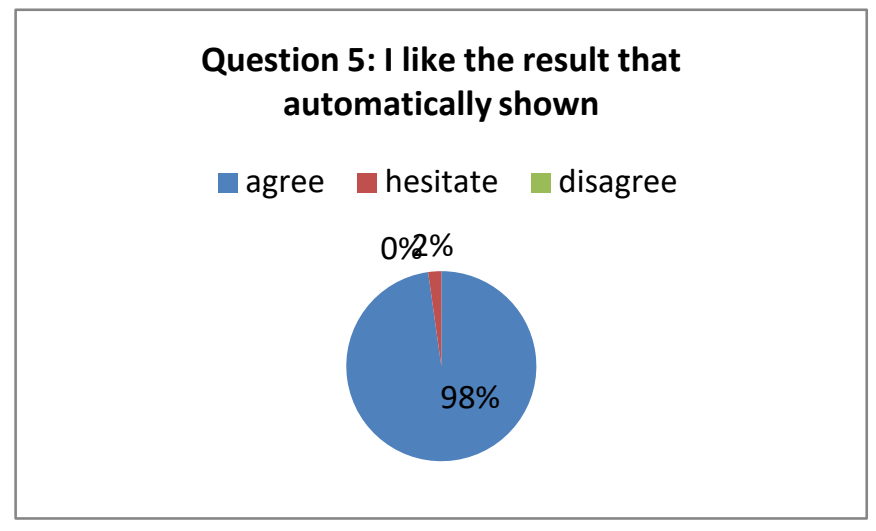

As many as $98 \%$ respondents like when they the result are automatically shown in the sceen.

6. This learning game is able to develop my learning motivation.

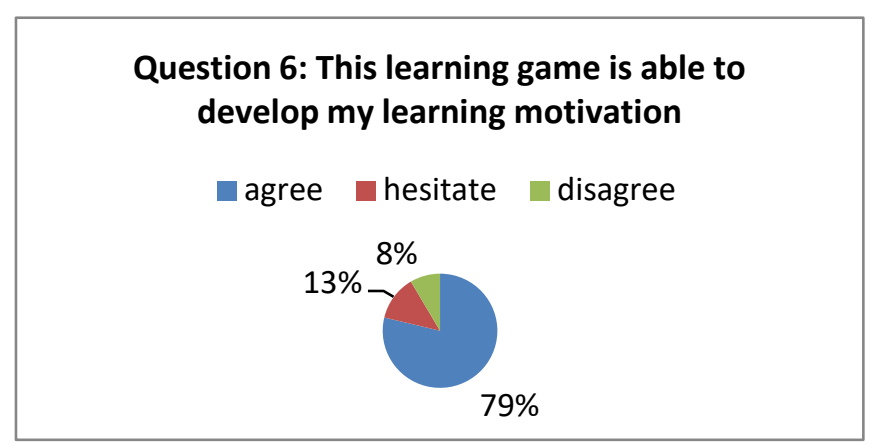

The diagram above shows that $79 \%$ of respondets agree that the Kahoot online learning game is able to develop their learning motivation.

7. The learning environtment become more fun and interesting. 


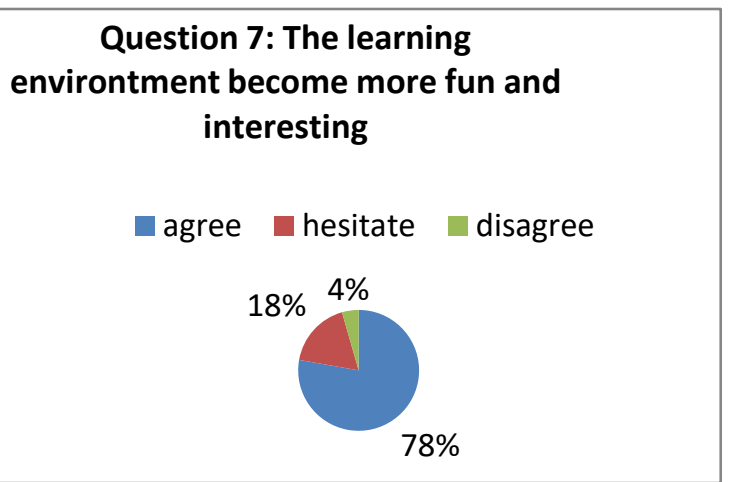

From the diagram above we san see that $78 \%$ of respondents agree that the learning environtment become more fun and interestng.

8. This learning game is able to develop the students' activity in the class.

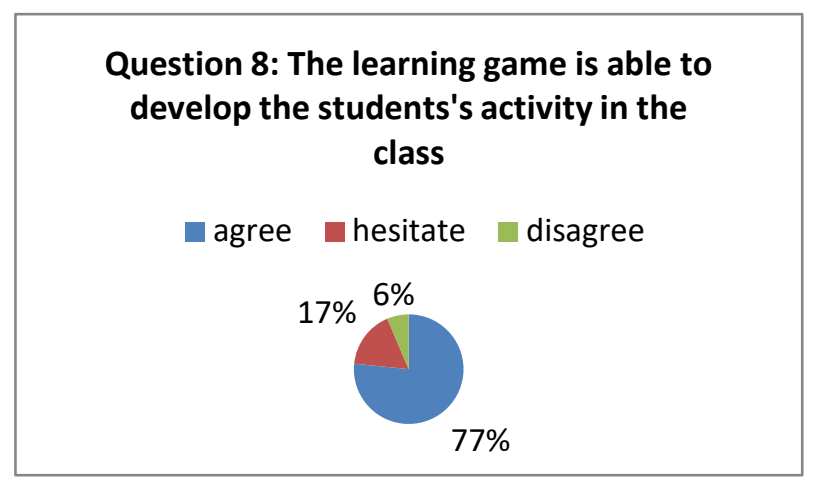

From the char we can see that $77 \%$ of the respondents agree that this game make them more active in learning.

9. The question given is suitable with the subject of the course.

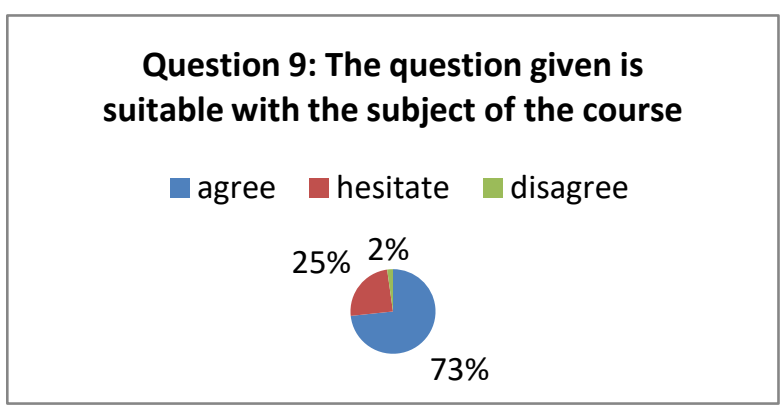

The diagtam shows that $73 \%$ respondents agree that he question given in the quiz are suitable with the subject of the course.

10. I always excited in answering the questions.

\section{Question 10: I always feel excited in answering the question}

agree hesitate disagree

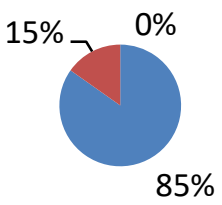

The diagram shows that $85 \%$ respondents are always feel excited in answering the questons.

Table 2. Students' opinion toward the obstacles faced by using Kahoot

\begin{tabular}{ll}
\hline No. & \multicolumn{1}{c}{ Questions } \\
\hline 1 & The problem inintemet connection \\
\hline 2 & The time given in answering the question is too fast. \\
\hline 3 & Sometimes the devices are not supported. \\
\hline
\end{tabular}

From the table above we can conclude that the students' obstacle mostly about the internet connection. Sometimes the connection is down. Besides that they also had a difficulties when answering the question to the limitation of time. It means that they need more time to think of the answer. And the last, the obstacle is the device that the students' have which are sometimes not supported, so that it make the connection down or buffering.

Table 3. Student's score in online Learning Evaluation by using Kahoot.

\begin{tabular}{|c|c|c|c|}
\hline \multicolumn{4}{|c|}{ FINAL SCORES } \\
\hline \multirow{2}{*}{ RANK } & \multirow{2}{*}{ TEAM } & \multicolumn{2}{|c|}{ SCORE } \\
\hline & & Paper Based-test & Kahoot \\
\hline 1 & 2 & 12 & 12 \\
\hline 2 & 6 & 12 & 12 \\
\hline 3 & 8 & 10 & 12 \\
\hline 4 & 1 & 9 & 10 \\
\hline 5 & 5 & 8 & 10 \\
\hline 6 & 10 & 8 & 8 \\
\hline 7 & 3 & 9 & 12 \\
\hline 8 & 7 & 9 & 9 \\
\hline 9 & 4 & 7 & 8 \\
\hline 10 & 9 & 2 & 9 \\
\hline
\end{tabular}

The table above shows that there is an inreasing score from the paper based test to Kahoot test by looking at the right answer from the question given. The enhacement can be described as follow: 


\section{The Enhancement of Students' Score}

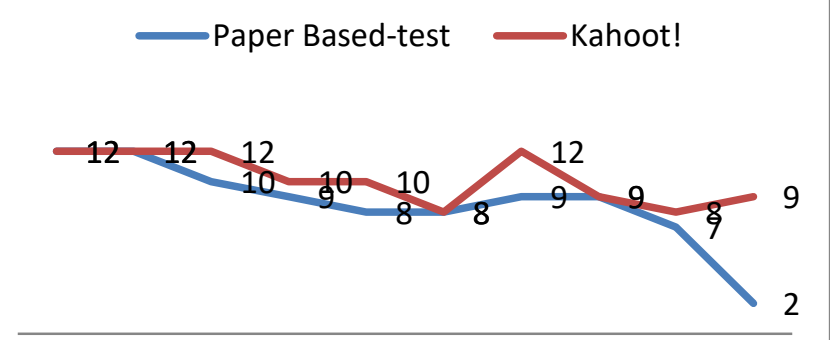

$\begin{array}{llllllllll}1 & 2 & 3 & 4 & 5 & 6 & 7 & 8 & 9 & 10\end{array}$

\section{CONCLUSION}

Based on the results of data analysis, it can be concluded that:

a. The use of Kahoot's media in learning provides benefits to students where they can be helped in recalling the material given, making them more excited, feeling happy, not feeling bored and being able to actively participate in doing the exercises. Besides that, they can discuss and collaborate in answering the questions displayed on the screen. They also liked the characteristics of the Kahoot game which gave rise to competition desires among students so they were challenged to be the best in the class.

b. The use of Kahoot's media can foster their interest and motivation in learning especially in Internet subject. With this increased interest and motivation, their knowledge also can be improved.

c. Constraints that occur in this learning media are more on devices and internet connections that not all students have appropriate devices, such as mobile devices and laptops, this factor is one of the supporters of Kahoot's media learning.

\section{REFERENCES}

Arsyad, A. (2013). Media Pembelajaran. Jakarta. Raja Grafindo Persada.

Bandung, M. (2017). Makalah disajikan dalam the Asian Conference on Education 2017. Official ConferenceProceedings.

Barus, Gloria, I., R dan Tatie, S. (2018). Penggunaan Media Kahoot Dalam Pembelajaran Struktur Bahasa Inggris Studi Kasus Mahasiswa Sekolah Vokasi Institut Pertanian Bogor. Seminar Nasional Teknologi dan Terapan Berbasis Kearifan Lokal (SNT2BKL) ISSBN: 978-602-71928-1-2

Ewa, P., Z. (2016) Kahoot It or Not? Can Games Be Motivating in Learning Grammar? Teaching English with Technology, v16 n3 p17-36 2016 (http: //eric.ed.gov/?id+EJ1135685, accessed on 29 Oktober 2018).

Kusumastuti, F. (2018), Perbedaan Respon Siswa Terhadap Penggunaan Kuis Klasik dan Kuis Kahoot. Program Studi Pendidikan Matematika. Universitas Sanata Dharma:Jogjakarta

Graham, Krista, LOEX Quarterly - Volume 42, (online), (http://commons.emich.edu/loexquarterly/vol42/iss3/, accessed on 3 November 2018).

Hakim, T. (2008). Belajar Secara Efektif. Jakarta: Pustaka Pembangunan Swadaya Nusantara.

Hermida, J. (2009). The importance of Teaching Academic Reading Skills in first-year university courses. SSRN Electronic Journal $3 . \quad$ (online), (http://www.researchgate.net/ accessed on 12 Nopember 2018).

Kahoot! (http://getkahoot.com/) diakses 30 Oktober 2018. Kahoot! (http://kahoot.com) accessed on 31 Oktober 2018.

Koesnandar, A. (2006). Pengembangan Software pembelajaran multimedia interaktif. Teknodik No. $18 / \mathrm{X}$.

Licorish, A.S. et al. (2017). Students' perception of kahoot!'s influence on teaching and learning. (https://doi.org/10.1177/2379298116689783)

Nasution. (1982). Teknologi Pendidikan.Bandung: Bumi Aksara.

Pemanfaatan Media Kahoot Pada Proses - USD Repository

repository.usd.ac.id/31078/2/141414034_full.pdf

(accessed on 2 Nopember 2018).

Priyitno, E. (1989). Motivasi Dalam Belajar. Jakarta: P2LPTK

Praherdhiono, H. (2018). Pembelajaran Berbasis WEB: Sebagai Pendekatan Media Pembelajaran Dalam Paradigma Konstuktivisme. Teknologi Pendidikan, Universitas Negeri Malang, (Online), (www.academia.edu/34226313/MEDIA_PEMBELAJ ARAN_BERBASIS_WEB, accessed on 4 Nopember 2018).

Richard, J \& Renandya, W. (2002). A Methodology in Language Teaching. United Kingdom: Cambridge UniversityPress.

Rofiyarti, F. (2017). TIK untuk AUD: Penggunaan Platform Kahoot. PEDAGOGI. (Online), (journal.umsurabaya.ac.id/index.php/Pedagogi/article/.../895 accessed on 30 Oktober 2018).

Sardiman, A,M. (1990). Interaksi dan Motivasi Belajar Mengajar. Jakarta: Rajawali. [Online]. 
Tersedia:https://kahoot.com/what-is-kahoot/ (accessed on 19 September 2018)

Susanto, Y. (2018). Using Kahoot to Increase Students' Motivation in Learning Japanese. Proceeding International Conference of Japanese Language Education (ICoJLE)

The $2014 \quad$ NMC Horizon Reports (http://www.nmc.org/nmc-horizon/) accessed on 1 November 2018.

Using Online Computer Games in the ELT Classroom: A Case Study. Available from: https://www.researchgate.net/publication/320928742 _Using_Online_Computer_Games_in_the_ELT_Clas sro om_A_Case_Study, accessed on 7 November 2018).

What is Kahoot!|How to play Kahoot! https://kahoot.com/what-is-kahoot/

Wijayanti, Hapsari, S dkk. (2013). Pemanfaatan multimedia dalam pembelajaran Bahasa Indonesia di perguruan tinggi. Laporan Penelitian. 